\title{
Benchmarking of the Transport Market with Hierarchical Clustering of Rail Companies
}

\author{
O.I.Zorina ${ }^{1}$, T.V.Neskuba ${ }^{1}$, O.M.Mkrtychyan ${ }^{1}$, V.A.Volokhov ${ }^{1}$ \\ ${ }^{I}$ Ukrainian State University of Railway Transport \\ *Corresponding author E-mail: neskubatv@gmail.com
}

\begin{abstract}
The article deals with the hierarchical clustering of operating rail national companies as the main stage of the benchmarking of Europe's rail transport market, which was proposed for the first time. It was established that at Euro integration the results of taxonomy make it possible to determine efficient areas of cooperation and provide a sufficient competitive level in the rail industry both for European counties and Ukraine. And an optimal criterion for cluster analysis, as was established, is the efficiency indices. Hence, the basic result in hierarchical clustering is division of rail companies into groups with similar performance characteristics. It will allow revealing the main competitors in the industry for each company on the basis of technical, geographic and economic conditions in a particular country. Detailed research of clusters with the k-means method made it possible to obtain more detailed information on characteristics of division and influence of factors on clusters. For accurate identification of characteristics for each cluster a single-factor dispersion analysis was performed. The analysis established the average value of an indicator for the clusters, standard deflection, maximal and minimal values. This information is required for development of the priority areas to improve the operating efficiency and ensure a sufficient competitive level in the rail industry of the EU countries.
\end{abstract}

Keywords: Benchmarking of transport market; Cluster analysis for the rail transport; Efficiency of railway operations; Hierarchical clustering; The $k$ means method.

\section{Introduction}

In the age of the world economy globalization the problems concerning integration of national economies are the most important for the research, because their solutions will contribute to higher efficiency of economic entities at each level. Maintenance of competitive relations between them, as the basic element of the market economy, is the major condition to provide a further growth of national economies and maintain momentum in the scientific and technological progress for a society in whole. Since the level of economic development of countries is substantially characterized by various economic environments, analysis, comparison and unbiased assessment of differences can help less developed structures reveal the key elements of the competitive opportunities of the leaders, and, thereby, increase the efficiency. It is especially urgent for the countries at the level of economic development, which requires introduction of effective and efficient techniques of economic activity. Thus, economically developed economies secure the changes and can profit from world economic growth.

One of the integration factors for economic systems is providing competitive conditions for entities in the transport market Transport plays an important role in the world economic development, for it ensures the reproduction. Therefore, a solution to the priority problems in the industry will contribute to more efficient interaction between economic systems on a global basis. Ukraine's transport market, at the current development stage, has a lot of problems. Their solutions will favor the transition of "the national economy to the phase of the country's intensive growth and integration to the European Union" [1]. It is crucial that four out of ten international transport corridors run through Ukraine. The rail transport plays the key role in Ukraine's transport industry and national economy. It accounts for 58\% of freight turnover and ensures 3\% of GDP for the country's economy [1]. Thus, analysis and assessment of the transport market of the rail industry will help outline some trends of development within European structures, and, also, further integration of Ukraine's transport sector to the European Union.

One of the efficient management tools in the age of the world economic globalization is benchmarking [2,3]. Europe's transport market applies this approach to reveal the leaders in the transport sector in order to improve efficiency of faltering enterprises and perfect the system of their interaction. Thus, benchmarking is a priority area in scientific research as a tool to increase competitiveness of rail transport enterprises under globalization.

\section{Analysis of Scientific Research and Publications on Benchmarking for Rail Transport Enterprises}

The peculiarities in terms of the benchmarking concept for Europe's transport market are connected with development of strategy to increase the competitiveness of transport companies by improving intermodal systems and reducing a negative environmental impact $[4,5]$.

The research dealing with benchmarking on the rail transport [6, 7] indicates that the basic reason to conduct it is a search for ways to increase competitiveness by introducing practices adopted by 
the leader in the field. The authors demonstrate that the existing benchmarking strategies prove its efficiency regarding improved performance of the rail transport. And the results depend on the degree of belief among all market participants [6].

The experience in benchmarking application proposed as a basic tool for analysis of efficiency factors for certain European rail systems proves that reliability of results depends on the key factors chosen and analysis techniques [7].

Application of benchmarking for improvement of business processes of production and management at rail enterprises assumes continuous perfection and introduction of the effective management principles for the reference structural subdivisions in certain industrial sectors [8]. It is supposed that the basic strategy is connected with the analysis of deviations in qualitative and quantitative indicators of business operation in certain industries with the reference ones.

Existing techniques to define key indicators for benchmarking are based on application of the indicators used for calculation of efficiency of rail structures $[9,10,11]$. Thus, the following basic efficiency indicators were determined: freight and passenger transportation cost efficiency, activity factor of rail infrastructure and freight/passenger rail operators. The strategy to reveal the leaders in the industry deals with application of the comparative analysis based on the ratings calculated [9].

The Boston Consulting Group developed the Railway Performance Index (RPI) for European countries as the main efficiency indicator in the rail industry [10]. Its basic components are the use intensity (freight and passenger turnover), service quality (accuracy of local trains, number of high speed railways, average fee per passenger per kilometre of the network), as well as safety (number of accidents per train-kilometre and mortality per a train-kilometre).

Calculation of the efficiency indicator, as the main criterion of rail transport operation, is the key element in the comparative analysis of operational results among participants of the International Union of Railways [11]. Quantitative efficiency indicators of the railway transport were the basis for calculation of the rating assessment, which determined the leaders in the industry.

It should be mentioned that integration of different economies and certain regions is connected with the establishment of markets for the leading industries, wherein companies differ by external and internal operational indicators. As far as technical, geographical and economic environments in a particular country directly influence the efficiency indicators of rail companies working in this country, their division by clusters, considering general operational characteristics, allow revealing direct competitors and outlining strategies for their interaction in market economy. It is an innovative solution in the benchmarking analysis of the transport market. Therefore, a search for unified key indicators, which can provide reliable results, is one of priority objectives of the research. Benchmarking can be successfully conducted due to objective qualitative efficiency indicators of rail companies while making cluster analysis of competitors operating in Europe's transport market.

\section{Investigation into Problems and Prospects of Benchmarking for Rail Companies in Europe's Transport Market under Globalization}

\subsection{Stages of Benchmarking for Europe's Rail Transport Market with Cluster Analysis Methods}

A search for ways to increase competitiveness and investment attractiveness of rail transport under integration of national economies of some European countries resulted in transformation processes and, further, establishment of rail holding companies. The basic reformation model implied establishment of joint-stock companies, wherein the control packet of shares belonged to the states where the rail transport operated. Establishment of competitive environment among private freight and passenger operators promoted rolling stock modernization and service quality improvement.

In Ukraine the public company "Ukrainian Railways" is a national freight and passenger operator. Since one of the main principles of benchmarking is measurability and analogy, that is business processes at enterprises put into comparison should be similar and evaluated by a single metrics, the rail transport market can be estimated on the basis of rail companies with similar operational environments (Table1).

Integration of Ukraine's railway transport to the Europe's transport market requires consideration of the fact that European rail holding companies have comparatively wide operational experience than that of Ukrainian Railways (Ukrzaliznytsia) founded in 2015. Taking into account differences in internal and external environments, the priority goals of the research is a search for such key indicators which in full guarantee the research objectivity and make it possible to ground the conclusions by results obtained.

The basic concept of cluster analysis is based on the data structuring of information on entities' activity into comparatively homogenous groups.

Market segmentation by main competitors will give an opportunity to determine the cluster of the market leaders among the rail companies and, thus, determine the key factors of their success.

Therefore, the structure of rail market segmentation can be presented as follows:

1) determination of the basic objectives of cluster analysis. The stage implies research into internal and external information on the companies' activity based on the systematic analysis and formation of a selection, which is the basis of clustering;

2) selection of a set of variables which reproduces similarities of the objects analyzed to the best advantage. The cluster analysis suggests the use of three basic types of variables: rank, qualitative and quantitative. Since units of measurement of valuables differ, it is necessary to standardize the data, which suggests that the mean value by a parameter is equal to zero, and dispersion is equal to one.

3) data processing by defining a degree of similarity of variables with calculation of the distance measure between them. The main goal at this stage is statistical processing of data by defining a degree of similarity which can be expressed by: correlation coefficient, measure of distance, associativity and probability factor of similarity. And the distances can be calculated with Manhattan distance, standard Euclidean distance, weighted Euclidean distance or Hamming distance;

4) establishment of groups of similar objects with the hierarchical agglomerate procedure. The main result at this stage is uniting groups of elements into clusters, considering the adopted distance, into one class. Similarity between classes of objects can be defined in calculation of the distance on the basis of the nearest neighbour, furthest neighbour, or average link;

5) building a dendrogram which helps define the number of clusters for a k-means analysis graphically;

$6) \mathrm{k}$-means clustering. The main goal of the method is calculation of mean factors for each cluster in order to assess the discrepancy between them. It will enable evaluating the activity of rail companies, determining a degree of influence for each variable on the overall performance and define factors of success in leading structures;

7) interpretation of the results obtained and propositions how to increase competitiveness of rail companies in Europe's transport market under globalization.

Thus, benchmarking of European rail companies will make it possible, on the basis of cluster analysis, to define groups of companies which are the main competitors within each cluster in Europe's transport market, to reveal the leader and to develop strategies for ensuring a sufficient competitive level. 
It should be mentioned that efficiency of results of the hierarchical method depends on the variables forming the foundation of cluster analysis; therefore, sampling is an important stage in implementation of planned steps.

Table 1: Rail holding companies in the European Union, selected for benchmarking

\begin{tabular}{|c|c|c|}
\hline Country & Name of the holding company & Abbreviation \\
\hline Austria & Österreichische Bundesbahnen & ÖBB \\
\hline Bulgaria & Български държавни железници & BDŽ \\
\hline Hungary & Magyar Államvasútak & MÁV \\
\hline Germany & Deutsche Bahn & DB \\
\hline Ireland & Iarnród Éireann & IÉ \\
\hline Spain & $\begin{array}{l}\text { Red Nacional de los Ferrocarriles } \\
\text { Españoles }\end{array}$ & RENFE \\
\hline Italy & Ferrovie dello Stato & FS \\
\hline Latvia & Latvijas dzelzceḷš & LDZ \\
\hline Lithuania & Lietuvos Geležinkkeliai & LG \\
\hline Norway & Norges Statsbaner & NS \\
\hline Poland & Polskie Koleje Państwowe & PKP \\
\hline Portugal & Comboios de Portugal & $\mathrm{CP}$ \\
\hline Rumania & Căile Ferate Române & CFR \\
\hline Slovakia & $\begin{array}{l}\text { Železničná spoločnost' Slovensko, } \\
\text { a. s. }\end{array}$ & ŽSSR \\
\hline Slovenia & Slovenske železnice & SŽ \\
\hline Turkey & $\begin{array}{l}\text { Türkize Cumhurizeti Devlet } \\
\text { Demirzolları İşletmesi }\end{array}$ & TCDD \\
\hline Finland & Valtion Rautatiet & VR \\
\hline France & $\begin{array}{l}\text { Société Nationale des Chemins de } \\
\text { fer Français }\end{array}$ & SNCF \\
\hline $\begin{array}{l}\text { Czech } \\
\text { Republic }\end{array}$ & České dráhy & $\mathrm{C} \mathrm{D}$ \\
\hline Estonia & Eesti Raudtee & EVR \\
\hline Macedonia & Македонски Железници & МЖ \\
\hline
\end{tabular}

\subsection{Determination of Key Performance Indicators from Rail Companies for Cluster Analysis}

Efficiency of any business is connected, first of all, with formation of a sufficient revenue level, which not only cover expenses, but also form reserves for its further growth. There is no doubt that assessment of finance indicators is an important stage in revealing leaders in the industry. But as far as the main output of the rail transport is freight and passenger transportation, the initial stage in the benchmarking analysis of the transport market can be efficiency of a rail company, which is connected with freight and passenger turnover volume, as well as intensity of rail network use.

Railway efficiency calculation should consider both the number of employees in main (operational) activity and rail production mileage, since these elements are fundamental for the calculation. Accordingly, the key indicators for European rail structures selected for the research are given in Fig. 1.

It should be noted that differences in the efficiency indicators in European countries are explained by various conditions, such as:

- geographical position (local topography, climatic conditions, etc.),

- different structure of freight and passenger transportation (national economic policies).

The indicators for the analysis were selected on the basis of availability of processing data, since a lot of holding companies concealed their insider performance information. The research data were taken from the Eurostat website and the 2016 Annual reports on rail transportation from rail companies, presented in fre e access basis at their official websites.

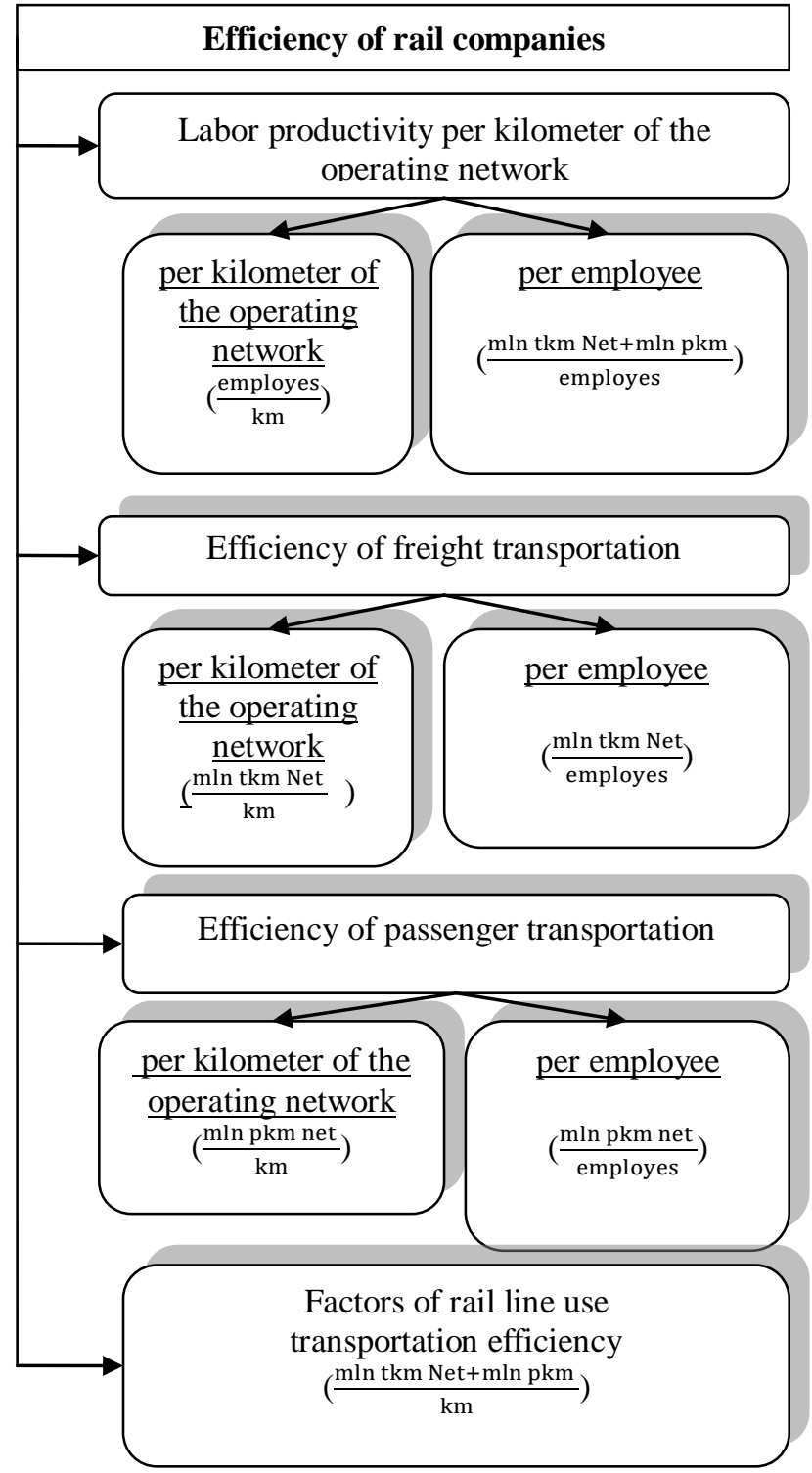

Fig. 1: Efficiency indicators of railways as the major variables for cluster analysis in benchmarking of Europe's rail transport market

As far as the benchmarking concept is to define the leader in a field, the grouping of rail companies in Europe's transport market will allow defining the basic performance criteria substantiating the results obtained. The assessment of success criteria for market leaders by each cluster gives an opportunity to formulate the basic recommendations to improve performance of rail companies in Europe's transport market under globalization.

One of the methods of the data structuring for revealing similar performance characteristics of rail companies is the hierarchical clustering based on a certain similarity or distance between normalized data by certain indicators.

Therefore, the results of the analysis were the information base for developing areas of effective cooperation and competitiveness by clusters.

\section{The Results of Cluster Analysis of Transport Market of Rail Companies in the European Union}

Since the variables for the analysis had different units of measure, they were standardized by calculating the centred value to standard deviation ratio.

The standardized indicators calculated were used for segmenting the rail transport market on the basis of the agglomerative hierarchical algorithm. 
The cluster analysis of rail companies was conducted with the treelike clustering method which suggests formation of clusters among the objects under consideration by calculating a distance between values of the standardized data obtained.

A standard Euclidean distance was used as a distance between the objects; the results made it possible to build a dendrogram as the basis for defining the number of "natural" clusters among the rail companies under study (Fig. 2).

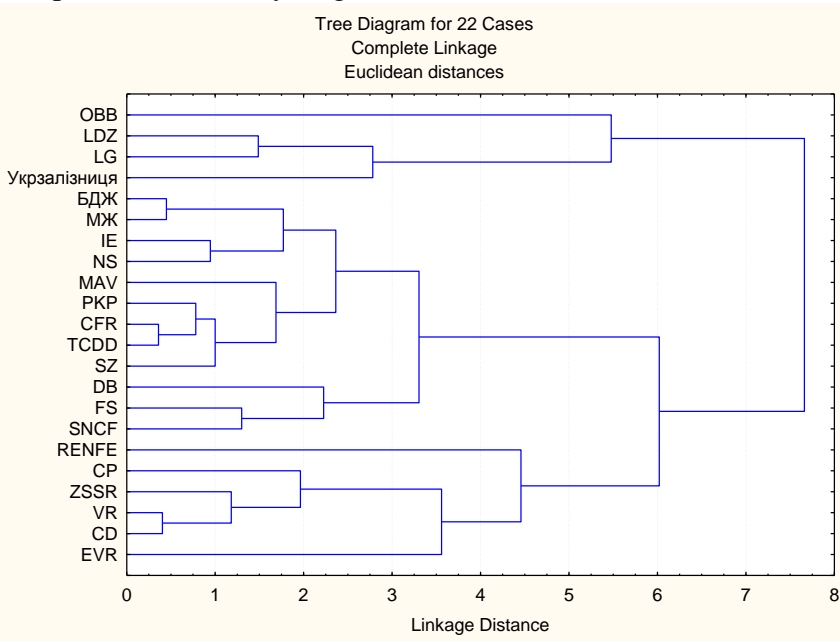

Fig. 2: The vertical dendrogram of the hierarchical clustering of efficiency indicators of European rail companies

Thus, the dendrogram graphically demonstrates that union and formation of "natural" clusters among European rail companies is possible and based on a distance between basic variables taken from efficiency indicators. The furthest neighbour method gives an opportunity to evaluate a distance between clusters by calculating the longest distance between objects in the cluster.

The visual rendering of the results makes it possible to define that European rail companies form four natural clusters:

- Cluster 1: ÖBB;

- Cluster 2: LDZ, LG, У3;

- Cluster 3: БДЖ, DB, MÁV, IÉ, FS, MЖ, NS, PKP, CFR, SŽ, TCDD, SNCF;

- Cluster 4: RENFE, CP, ŽSSR, VR, ČD, EVR.

The scheme of union presented in Fig. 3 testifies that the optimal number of clusters was determined.

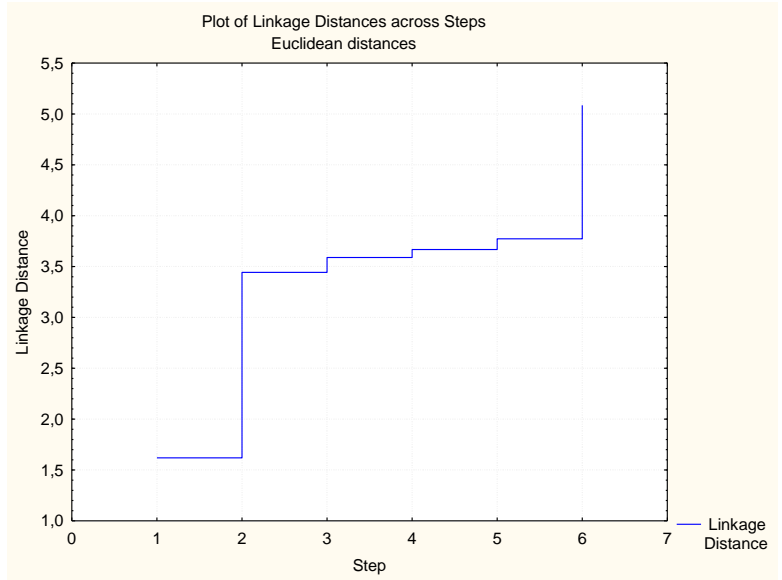

Fig. 3: The diagram of distances of the union by steps in cluster analysis

So, for more thorough investigation into the importance of differences between the clusters obtained the k-means clustering method was used; it enabled the authors to check the results of the previous analysis and select the basic variables forming them.

Due to computation it was established that the differences between the clusters obtained were significant as $p<0.05$ (Table 2) Taking into account the amplitudes (F) and levels of significance, it was possible to conclude that the most significant for the rail company distribution by clusters are: - labour productivity per employee;

- freight transportation efficiency per kilometre of the operating network;

- transportation efficiency.

Table 2: The variance analysis of differences between clusters

\begin{tabular}{|l|c|c|c|c|c|c|}
\hline Variable & $\begin{array}{c}\text { Betwee } \\
\mathrm{n}-\mathrm{SS}\end{array}$ & $\begin{array}{c}\mathrm{C} \\
\mathrm{C}\end{array}$ & $\begin{array}{c}\text { Inside } \\
\mathrm{SS}\end{array}$ & $\begin{array}{c}\mathrm{C} \\
\mathrm{C}\end{array}$ & $\mathrm{F}$ & Signif. $\mathrm{p}$ \\
\hline $\begin{array}{l}\text { Employee/ } \\
\mathrm{km}\end{array}$ & 12.770 & 3 & 8.229 & 18 & 9.310 & 0.000618 \\
\hline $\begin{array}{l}\text { Mln tkm } \\
\text { +mln pkm) } \\
\text { / employee }\end{array}$ & 16.632 & 3 & 4.368 & 18 & 22,849 & 0.000002 \\
\hline $\begin{array}{l}\text { Mln } \\
\text { tkm/km }\end{array}$ & 19.223 & 3 & 1.7769 & 18 & 64.913 & 0.000000 \\
\hline $\begin{array}{l}\text { Mln tkm/ } \\
\text { employee }\end{array}$ & 13.787 & 3 & 7.213 & 18 & 11.469 & 0.000195 \\
\hline $\begin{array}{l}\text { Mln pkm/ } \\
\mathrm{km}\end{array}$ & 12.035 & 3 & 8.965 & 18 & 8.054 & 0.001302 \\
\hline $\begin{array}{l}\text { Mln pkm/ } \\
\text { employee }\end{array}$ & 8.579 & 3 & 12.421 & 18 & 4.144 & 0.021316 \\
\hline $\begin{array}{l}\text { (Mln } \\
\text { tkm+mln } \\
\text { pkm) / km }\end{array}$ & 17.446 & 3 & 3.554 & 18 & 29.451 & 0.000000 \\
\hline
\end{tabular}

Table 3 presents calculation of the Euclidean distance between clusters. It demonstrates that the shortest distance between objects in Cluster 2 Cluster 3 (Euclidean distance $=1.138728$ ), the longest distance is 3.247328 (Cluster 1 and Cluster 3).

Table 3: The Euclidean distance between clusters

\begin{tabular}{|l|c|c|c|c|}
\hline & Cluster 1 & Cluster 2 & Cluster 3 & Cluster 4 \\
\hline Cluster 1 & 0.000000 & 1.436329 & 3.247328 & 2.625258 \\
\hline Cluster 2 & 1.198469 & 0.000000 & 1.296701 & 2.171190 \\
\hline Cluster 3 & 1.802034 & 1.138728 & 0.000000 & 1.911658 \\
\hline Cluster 4 & 1.620265 & 1.473496 & 1.382627 & 0.000000 \\
\hline
\end{tabular}

In order to define characteristics in each cluster, a diagram of the mean values of variables for the clusters was built. It is presented in Fig. 4.

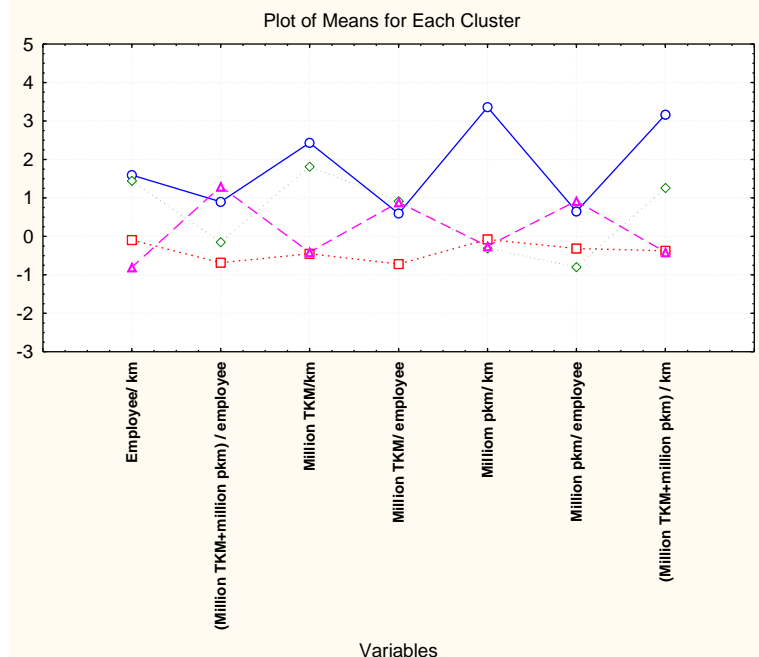

Fig. 4: The diagram of the average values of variables for each cluster In order to find out detailed characteristics of each cluster, the methods of the single-factor variance analysis were used. The analysis established the average value of an indicator by clusters, standard deflection, maximal and minimal values (Table 4).

On the base of the research data obtained it is possible to find the key performance factors for rail companies in Europe's transport market.

Analysis of the hierarchical clustering of rail companies and application of k-means clustering demonstrated that each cluster has a number of similar characteristics defining an efficiency level of the objects. 
The basic characteristics of Cluster 1, considering that the mean value of an indicator was calculated for one company, are (Fig. 4, Table 4):

- average labour productivity per kilometre of the operating network is higher than the same indicator in Cluster 2, but lower than the maximum value of the indicator for one out of three objects in the cluster. It indicates that the number of main employees per kilometre of the operating network is higher than the average value;

- average labour productivity per employee is lower, than the average value in Cluster 4. The main conclusion is the number of employees involved in the freight and passenger turnover is lower than the average value, which testifies to high automation of operational activity;

Table 4: The descriptive statistics of the main indicators by taxonomy of rail companies

\begin{tabular}{|c|c|c|c|c|c|}
\hline Cluster & $\begin{array}{c}\text { Average } \\
\text { indicator } \\
\text { value } \\
\end{array}$ & $\begin{array}{c}\text { Number } \\
\text { of } \\
\text { objects }\end{array}$ & $\begin{array}{l}\text { Standard } \\
\text { deflection }\end{array}$ & Minimum & Maximum \\
\hline \multicolumn{6}{|c|}{ Labour efficiency per kilometre of the operating network, $\frac{\text { employes }}{\mathrm{km}}$} \\
\hline $\begin{array}{l}\text { Cluster } \\
1\end{array}$ & 8.624000 & 1 & 0.000000 & 8.624000 & 8.62400 \\
\hline $\begin{array}{l}\text { Cluster } \\
2\end{array}$ & 8.165333 & 3 & 2.894071 & 5.283000 & 11.07100 \\
\hline $\begin{array}{l}\text { Cluster } \\
3\end{array}$ & 3.290833 & 12 & 2.436243 & 1.162000 & 9.17800 \\
\hline $\begin{array}{l}\text { Cluster } \\
4\end{array}$ & 1.033667 & 6 & 0.448243 & 0.515000 & 1.63400 \\
\hline \multicolumn{6}{|c|}{ Labour productivity per employee, $\frac{\mathrm{mln} \text { tkm Net+mln pkm }}{\text { employes }}$} \\
\hline $\begin{array}{l}\text { Cluster } \\
1\end{array}$ & 1.775000 & 1 & 0.000000 & 1.775000 & 1.775000 \\
\hline $\begin{array}{l}\text { Cluster } \\
2\end{array}$ & 1.053333 & 3 & 0.334566 & 0.739000 & 1.405000 \\
\hline $\begin{array}{l}\text { Cluster } \\
3\end{array}$ & 0.685250 & 12 & 0.281508 & 0.128000 & 1.078000 \\
\hline $\begin{array}{l}\text { Cluster } \\
4\end{array}$ & 2.047833 & 6 & 0.439280 & 1.604000 & 2.731000 \\
\hline \multicolumn{6}{|c|}{$\begin{array}{l}\text { Efficiency of freight transportation per kilometre of the network, } \\
\qquad \frac{\text { mln tkm Net }}{\text { employes }}\end{array}$} \\
\hline $\begin{array}{l}\text { Cluster } \\
1\end{array}$ & 9.236000 & 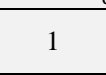 & 0.000000 & 9.236000 & 9.23600 \\
\hline $\begin{array}{l}\text { Cluster } \\
2\end{array}$ & 7.475333 & 3 & 1.750433 & 5.904000 & 9.36200 \\
\hline $\begin{array}{l}\text { Cluster } \\
3\end{array}$ & 1.069917 & 12 & 0.757898 & 0.042000 & 2.83700 \\
\hline $\begin{array}{l}\text { Cluster } \\
4\end{array}$ & 3.193167 & 6 & 4.884809 & 0.558000 & 13.09300 \\
\hline \multicolumn{6}{|c|}{ Efficiency of freight transportation per employee, $\frac{\mathrm{mln} \text { tkm Net }}{\text { employes }}$} \\
\hline $\begin{array}{l}\text { Cluster } \\
1\end{array}$ & 1.071000 & 1 & 0.000000 & 1.071000 & 1.071000 \\
\hline $\begin{array}{l}\text { Cluster } \\
2\end{array}$ & 1.243667 & 3 & 0.355331 & 0.846000 & 1.530000 \\
\hline $\begin{array}{l}\text { Cluster } \\
3\end{array}$ & 0.372250 & 12 & 0.220674 & 0.027000 & 0.728000 \\
\hline $\begin{array}{l}\text { Cluster } \\
4\end{array}$ & 1.226000 & 6 & 0.500972 & 0.730000 & 2.123000 \\
\hline \multicolumn{6}{|c|}{$\begin{array}{c}\text { Efficiency of passenger transportation per kilometre of the network, } \\
\frac{\mathrm{mln} \text { pkm }}{\mathrm{km}}\end{array}$} \\
\hline $\begin{array}{l}\text { Cluster } \\
1\end{array}$ & 6.069000 & 1 & 0.000000 & 6.069000 & 6.069000 \\
\hline $\begin{array}{l}\text { Cluster } \\
2\end{array}$ & 0.757000 & 3 & 0.982081 & 0.120000 & 1.888000 \\
\hline $\begin{array}{l}\text { Cluster } \\
3\end{array}$ & 1.093833 & 12 & 1.180206 & 0.092000 & 3.184000 \\
\hline $\begin{array}{l}\text { Cluster } \\
4\end{array}$ & 0.833833 & 6 & 0.556686 & 0.148000 & 1.676000 \\
\hline \multicolumn{6}{|c|}{ Efficiency of passenger transportation per employee, $\frac{\mathrm{mln} \text { pkm }}{\text { employes }}$} \\
\hline $\begin{array}{l}\text { Cluster } \\
1\end{array}$ & 0.704000 & 1 & 0.000000 & 0.704000 & 0.704000 \\
\hline $\begin{array}{l}\text { Cluster } \\
2\end{array}$ & 0.083667 & 3 & 0.076166 & 0.031000 & 0.171000 \\
\hline
\end{tabular}

\begin{tabular}{|l|c|c|c|c|c|}
\hline $\begin{array}{l}\text { Cluster } \\
3\end{array}$ & 0.291167 & 12 & 0.231654 & 0.010000 & 0.749000 \\
\hline $\begin{array}{l}\text { Cluster } \\
4\end{array}$ & 0.821167 & 6 & 0.581606 & 0.287000 & 1.865000 \\
\hline $\begin{array}{l}\text { Eluster } \\
1\end{array}$ & 15.30500 & 1 & 0.000000 & 15.30500 & 15.30500 \\
\hline $\begin{array}{l}\text { Cluster } \\
2\end{array}$ & 8.23233 & 3 & 2.705371 & 6.02400 & 11.25000 \\
\hline $\begin{array}{l}\text { Cluster } \\
3\end{array}$ & 2.17225 & 12 & 1.683608 & 0.33600 & 5.58300 \\
\hline $\begin{array}{l}\text { Cluster } \\
4\end{array}$ & 2.02783 & 6 & 0.800718 & 1.24100 & 3.26900 \\
\hline
\end{tabular}

- the freight transportation indicator is higher than its average value among other clusters, but lower than the maximum value in Cluster 4. Therefore, the freight transportation volume is lower than the traffic capacity in the network;

- the freight transportation efficiency per employee is lower than the average values in other clusters, which testifies to excess of the number of employees in comparison with freight turnover that the rail company provides;

- a higher value of the passenger transportation efficiency than the average values in other clusters testifies to a greater volume of passenger capacity per kilometre of the operating rail network;

- the efficiency indicator of passenger transportation per employee is lower than a similar average indicator of objects in Cluster 4, which testifies to higher automation of the production process;

- transportation efficiency is higher than the average values of indicators of objects in the other clusters and higher than the maximum values of one out of three objects from Cluster 2, which testifies to the leading position of the rail company to other ones;

The objects from Cluster 2 are characterized by the following:

- in spite of the fact that the maximum value of the labour efficiency indicator per kilometre of the operating network is higher than that of all the objects from the other clusters, but the average value of the indicator is lower than that in Cluster 1 and higher than similar indicators in Cluster 3 and Cluster 4. It indicates the average employment level of the rail operating network;

- the labour efficiency indicator per employee is lower than that in Cluster 1 and Cluster 4, but higher than that in Cluster 3, which means a sufficiently low employment density;

- at a sufficiently high average freight transportation efficiency indicator per kilometre of the network, which exceeds the value of a similar indicator in Cluster 3 and Cluster 4, it is lower than that in Cluster 1;

- the average value of the freight transportation efficiency indicator per employee among the specified three objects in a cluster is higher than similar indicators in other clusters. It is explained by greater volume of freight traffic handled by the rail company staff;

- the passenger transportation efficiency per kilometre of the network and per employee is lower than that in other clusters. The reason of it is a special structure of rail transportation companies wherein the aggregate freight turnover is higher than passenger turnover;

- among the average transport efficiency indicators the objects in Cluster 2 have a higher value, than that in Cluster 3 and Cluster 4, but lower by 1.86 than the indicator in Cluster 1 . And the authors came to conclusion that the indicator is higher than the average one, which testifies to sufficient use of the rail operating network. Twelve rail companies in Cluster 3 have the following characteristics in terms of the railway efficiency:

- at the second maximum value of the labour efficiency indicator per kilometre of the operating network, after an object in Cluster 1 , the average value of this indicator is lower than that in Cluster 1 and Cluster 2, but higher than in Cluster 4. This implies the sufficiently low number of employees servicing the operating network;

- the freight transportation efficiency per employee and per kilometre of the network is lower, than similar indicators in 
Cluster 1, Cluster 2 and Cluster 4. It implies a low freight turnover volume among the objects in the cluster;

- although the average passenger transportation efficiency value is higher than values of this indicator in Cluster 2 and Cluster 4, it is lower than in Cluster 1. It testifies to predominance of passenger transportation over freight transportation;

- the transport efficiency indicator is virtually at the same level as the indicator in Cluster 4, and lower than similar indicators in Cluster 1 and Cluster 2. This state is typical for rail companies which efficiency indicators are lower than the average indicator in comparison with other clusters.

The basic characteristic in Cluster 4 is connected with an excess of the labour efficiency indicator per employee. The indicator exceeds similar indicators in Cluster 1, Cluster 2 and Cluster 3. By other indicators Cluster 4 has the lowest values.

Thus, Cluster 1 is characterized by:

- a rather even freight and passenger turnover distribution across the transportation structure;

- a high level of automation of operation;

- high efficiency of the transport network.

The basic characteristics of rail companies in Cluster 2 are:

- an excess of freight traffic over passenger traffic in the transportation structure;

- a low level of automation of transportation processes;

- an average level of transport infrastructure use.

Cluster 3 united rail companies of the following features:

- an excess of passenger traffic over freight traffic in the transportation structure;

- an insufficient level of the network's traffic capacity use;

- a high level of automation of transportation processes;

Cluster 4 includes rail companies of a high degree of automation of production processes and relatively low level of freight and passenger turnover in comparison with other rail companies in Europe.

\section{Conclusions}

Clustering analysis of rail companies in the transport market of the EU countries in terms of benchmarking established the following:

1) taking into account a specific nature of rail transport operation in Ukraine, among the key indicators providing efficient benchmarking the following rail transport efficiencies were defined: labour efficiency per kilometre of the operating network, labour efficiency per employee, freight transportation efficiency per kilometre of the network and per employee, passenger transportation efficiency per kilometre of the network and per employee, transportation efficiency;

2) the hierarchical clustering made it possible to group rail companies in Europe's transport market by similarity performance characteristics, to define the priority areas in order to improve their performance and ensure a sufficient competitive level in each cluster under globalization. It was established that European rail companies form four "natural" clusters;

3 ) the k-means clustering established that the basic variables influencing the distribution of rail companies by similarity are the labour productivity per employee, freight transportation efficiency per kilometre of the operating network and transportation efficiency;

4) it was established that a rail company, an only object of Cluster 1 , had the highest efficiency indicators of the railway lines. Among the basic factors influencing the high performance values are a great amount of passenger and freight turnover serviced by comparatively few employees due to a high level of automation of production processes.

Thus, the group of rail companies by clusters allows selecting leaders among the groups formed and, thus, defining areas for growth on the basis of the analysis of a competitor with similar activity. Hence, the main priority areas of the rail transport development in Ukraine, under its integration to Europe's transport market by analyzing the competitors by a cluster, are management restructuring, rationalization of the staff employed in the basic activity, and increase in the working process automation in structural divisions.

\section{References}

[1] Sych E.M., Boiko O.V. (2014) Terms and directions of providing effective development of Ukrainian transport market. Actual problems of economics 7, 125-132.

[2] Wobbe Werner, Benchmarking methods and their application, Transport benchmarking: Methodologies, Applications and Data Needs. European Conference of Ministers of Transport, (2000), 9 17.

[3] Stapenhurs T., The benchmarking Book, Elsevier, (2009).

[4] Deiss Richard, Benchmarking European transport, Transport benchmarking: Methodologies, Applications and Data Needs, European Conference of Ministers of Transport, (2000). 35-53.

[5] Barlund Gunnar, Benchmarking in transport, Transport benchmarking: Methodologies, Applications and Data Needs, European Conference of Ministers of Transport, (2000), 19-33.

[6] Anderson Richard J., Hirsch Robin C., Trompet Mark, Adeney William E., Developing Benchmark Methodologies for Railway Infrastructure, (2003), available online: http://www3.imperial.ac.uk/pls/portallive/docs/1/8597698.PDF, last visit: 10.05 .2018

[7] Hansen I.A., Wiggenraad P.B.L., Wolff J.W., (2013), Benchmark analysis of railway networks and undertakings, Rail Copenhagen 2013: 5th International Conference on Railway Operations Modelling and Analysis, Copenhagen, Denmark, 13-15 May 2013 International Association of Railway Operations Research (IAROR), available online:https://pdfs.semanticscholar.org/4efd/03bbb54c47d77d8954e 788cf3be00c8ecf3b.pdf, last visit: 01.05.2018

[8] Prudnikov AA, K voprosy o primenenii benchmarkinga na jelesnodorognom transporte. Sibirskaya finansovaja shkola, No.2, (2015), pp.78-80.

[9] Beck Arne, Bente Heiner, Schilling Martin, Railway efficiency - an overview and a look at opportunities for improvement, Discussion paper of International Transport Forum 2013-12, (2013), OECD/ITF.

[10] Duranton Sylvain, Audier Agnes, Hazan Joel, Mads Peter, Langhorn Vincent Gauche, The 2017 European Railway Performance Index, The Boston Consulting Group, (2017), available online: https://www.bcg.com/ru-ru/publications/2017/transportation-traveltourism-2017-european-railway-performance-index.aspx, last visit: 11.05.2018

[11] Eytutis G., Nikiforuk O., Karpov V., Productivnist jak efectivnist roboty zaliznits Ukraini, Ukrainski zaliznitsi, Vol.9-10, No.27-28, (2015), pp.46-49 